\title{
LUT
}

University

\section{Numerical analysis on utilizing excess steam for electricity production in cruise ships}

Uusitalo Antti, Nerg Janne, Grönman Aki, Nikkanen Samuli, Elg Mia

This is a Final draft version of a publication

published by Elsevier

in Journal of Cleaner Production

DOI: $\quad 10.1016 /$ j.jclepro.2018.10.279

Copyright of the original publication: () Elsevier Ltd. 2019

Please cite the publication as follows:

Uusitalo, A., Nerg J., Grönman, A., Nikkanen, S., Elg, M. (2019). Numerical analysis on utilizing excess steam for electricity production in cruise ships. Journal of Cleaner Production, Vol. 209, ss. 424-438. DOI: 10.1016/j.jclepro.2018.10.279

This is a parallel published version of an original publication.

This version can differ from the original published article. 


\title{
Numerical analysis on utilizing excess steam for electricity production in cruise ships
}

\author{
Antti Uusitalo*+, Janne Nerg+, Aki Grönman*+, Samuli Nikkanen*, Mia Elgo \\ * Saimaa University of Applied Sciences, 53851, Lappeenranta, Finland \\ + Lappeenranta University of Technology, School of Energy Systems, P.O. Box 20, 53851 Lappeenranta, Finland \\ o Deltamarin, 00210, Helsinki, Finland
}

\begin{abstract}
Marine sector has a significant contribution to the global greenhouse gas emissions and energy usage. Despite that the energy efficiency of ship engines has been increased drastically and the usage of new type of fuels such as $L N G$ has reduced the emissions, significant improvements in the energy efficiency of ship energy systems could be still achieved by the more effective usage of different heat streams. In this study, the potential for producing electric power from excess steam of large cruise ships is investigated. The analysis is carried out for annual operational profiles of case cruise ships and the excess steam utilization is studied by means of 0.5 MW to 2 MW scale steam turbine system and a combination of steam turbine and low temperature ORC system. A notable potential in utilizing the excess steam into electricity production was identified. It was observed that due to the high variations in the ship operation, the steam turbine design power and off-design performance have a significant impact on the electrical energy production. In the studied case cruise ships, steam turbine having a low condensing temperature or a combination of steam turbine and low temperature ORC reached the highest annual electric energy production potential, ranging from $3920 \mathrm{MWh} / \mathrm{a}$ to 5310 $M W h / a$.
\end{abstract}

Keywords: Cruise ship energy balance, Excess steam utilization, Efficiency increase, Steam turbine,

Waste heat recovery, Organic Rankine Cycle

\section{Nomenclature}

Latin alphabet

$P$ power $\mathrm{W}$

$h$ enthalpy $\mathrm{kJ} / \mathrm{kg}$

$p$ pressure $\mathrm{Pa}$, bar

$T$ temperature ${ }^{\circ} \mathrm{C}$

$q_{m}$ mass flow rate $\mathrm{kg} / \mathrm{s}$

$E$ energy production Wh

$x$ factor for steam turbine power limit -

$d$ turbine diameter $\mathrm{m}$

$C$ capacity factor

Email address: Corresponding author: antti.uusitalo@lut.fi (Antti Uusitalo*+, Janne Nerg+, Aki Grönman*+, Samuli Nikkanen*, Mia $\operatorname{Elg}^{o}$ ) 
$q_{v}$ volumetric flow rate $\mathrm{m}^{3} / \mathrm{s}$

$N_{s}$ turbine specific speed

$D_{S}$ turbine specific diameter

\section{Greek alphabet}

$\eta$ efficiency -

$\varsigma$ steam turbine off-design correction factor -

$\omega$ angular speed $\mathrm{rad} / \mathrm{s}$

\section{Subscripts}

a annual

$\mathrm{s}$ isentropic

c condensation/condenser

e electric

g generator

t turbine

in inlet

out outlet

off off-design condition

\section{Abbreviations}

ORC Organic Rankine cycle

LT Low temperature

LNG Liquefied natural gas

TEG Thermoelectric generator

WHR Waste heat recovery

\section{Introduction}

During the last decades, significant efforts on reducing global emissions to the atmosphere as well as increasing energy efficiency of different types of power generation systems have been carried out. One of the globally significant energy usage sectors is the marine sector which has been estimated to be producing about $3 \%$ of the global greenhouse gas emissions [1] and thus, the energy usage and emission reduction in marine sector will have a high importance in achieving the global emission reduction targets in the near 
future. Modern ships are equipped with multiple rather recently developed and complex technologies, and thus, it is important to be able to asses and compare the different technologies not only by taking into account the economic benefits of the technology, but also to take into account the sustainability aspects of various designs and technologies. It has been suggested that a methodology taking into account the environmental, economic and social sustainability of marine technologies can be used for measuring and evaluating the sustainability of different technologies[2].

Alongside with the recent developments in the efficiency of the ship engines and the usage of more environmentally friendly fuels, such as LNG[3], the utilization and control of the waste heat streams have drawn increasing attention in the recent times and contains high potential for increasing the overall efficiency of ship energy systems. Baldi and Gabrielii [4] evaluated in their study that there can be significant, from about $5 \%$ to $15 \%$, fuel reduction potential by utilizing the different waste heat streams of a studied case ship. In addition, the use of waste heat recovery systems has been identified to be an effective way to decline the greenhouse gas emissions to the atmosphere in engine systems and industrial processes $[5,6,7]$.Singh and Pedersen [8] reviewed the literature related to the potential technologies for recovering waste heat in marine applications. They recognized different types of waste heat recovery systems, including conventional steam Rankine process, organic Rankine cycle (ORC), Kalina cycle, advanced turbocharging, and thermoelectric generators (TEG) as potential technologies for different types of maritime applications.

It has been shown, that by converting the exhaust gas heat into electricity by using different waste heat recovery technologies, significant power output increase can be achieved for large scale engine systems. The utilization of exhaust gas heat has been studied by using various WHR technologies and in general, the recovery of exhaust gas heat of different types of engines have been the most intensively studied method for improving the overall efficiency in various types of engine systems [9]. Larsen et al. [10] investigated and modeled different technologies for utilizing exhaust gas heat in marine applications. They found a 7\% increase with ORC and a $5 \%$ increase in the ship energy production with steam turbine cycle or Kalina cycle. In addition, higher energy efficiency increase potential of up to $10 \%$ by using ORC systems adopting different working fluids, have been estimated for large engine systems[11, 12]. The potential of using Kalina cycles adopting a mixture of ammonia and water as the working fluid has been also identified[11, 13] representing comparable efficiency increase for the system when compared to ORC technology. Theotokatos et al. [14] evaluated an efficiency increase in the range from $3.2 \%$ to $3.5 \%$ in the case of LNG fired dual fuel marine engine when using a single pressure level steam turbine system. In addition, commercial small-scale steam turbines or combination of power turbines and steam turbines have been designed for increasing the overall efficiency of the ship energy system up to $10 \%[15,16]$. The use of steam turbines for recovering exhaust heat in large-scale engine power plants has been also considered and the efficiency increase potential in the engine power plant of about $9 \%$ has been estimated [17]. The waste heat recovery in gas turbine systems has been also investigated and the results have indicated a significant potential for increasing the system 
overall efficiency $[18,19]$. More recently, advanced WHR technologies such as systems using supercritical carbon dioxide as the working fluid for recovering high temperature heat have been investigated, showing potential for reaching further efficiency increases in marine power systems [20].

In addition to technologies utilizing high temperature exhaust gas heat, different type of processes that are capable of converting low temperature waste heat into electricity have been studied and proposed. The most commonly considered waste heat recovery systems for low temperature heat to electricity conversion have been the use of ORCs or TEGs. At the current technology level ORCs can achieve higher performances while the development of new materials for thermoelectric generators could narrow the gap between these two technologies in the future [21,22]. Ahlgren et al. [23] carried out a thermodynamic study for using ORC for recovering waste heat in the case of a cruise ship. They considered the utilization of a simple and regenerative cycle configuration as well as different working fluid candidates. Their results indicated that the ORC system can contribute up to $22 \%$ of the total electricity demand of the studied vessel and could have a significant potential for fuel savings and emission reductions. Grljusic et al. [24] studied the use of ORC for recovering waste heat and producing electricity and heat in an oil tanker. The studied system utilized R245fa as the working fluid. They concluded that the combined ORC and engine system can meet the onboard demand for electric and heat power generation, except a small portion of heat that has to be produced with ship auxiliary boilers. Song et al. [25] investigated the combined utilization of exhaust heat and jacket cooling water heat by using ORCs. They examined the performance of the ORC system with different fluids. By utilizing the exhaust gas and jacket cooling water heat of the engines an $10.2 \%$ increase in engine power output was reached in their study. In order to simplify the WHR system architecture they suggested to use the low temperature heat for preheating the working fluid in the process instead of using two separate ORC systems. More recently, Rech et al. [26] investigated numerically the use of ORC system recovering low temperature waste heat in a LNG carrier. R245fa was adopted as the working fluid in their study. They concluded that significant annual energy production of $1665 \mathrm{MWh} / \mathrm{a}$ and $2306 \mathrm{MWh} / \mathrm{a}$ can be reached with a one stage and two stage ORC system respectively from the low temperature waste heat of the ship engines.

This study concentrates on utilizing waste heat recovery systems in modern cruise ships. One of the specific features related to cruise ship energy systems, when compared to other ship types, is the high consumption of electric power during the operation that has to be produced alongside with the required propulsion power. In addition, in modern cruise ships a significant portion of the thermal energy that is not converted to useful energy in the engines is already utilized for the ship heating by recovering the exhaust gas thermal energy, and by producing pressurized steam in the ship exhaust boilers. This hot steam is used for distributing the heat power for various steam consumers. Thus, especially in cruise ships the exhaust gas waste heat is already utilized in a relatively efficient way and it is difficult to implement different types of WHR system for producing electric power directly from the exhaust heat. However, when a cruise ship is 
operated at high engine loads, the exhaust steam boilers are capable to produce more steam than is needed by the ship heat consumers. Thus, there can be significant potential for the utilization of this excess steam flow into additional electricity production. A simplified energy distribution, considering a normal operation cycle of a cruise ship having an electric propulsion is illustrated in Figure 1.

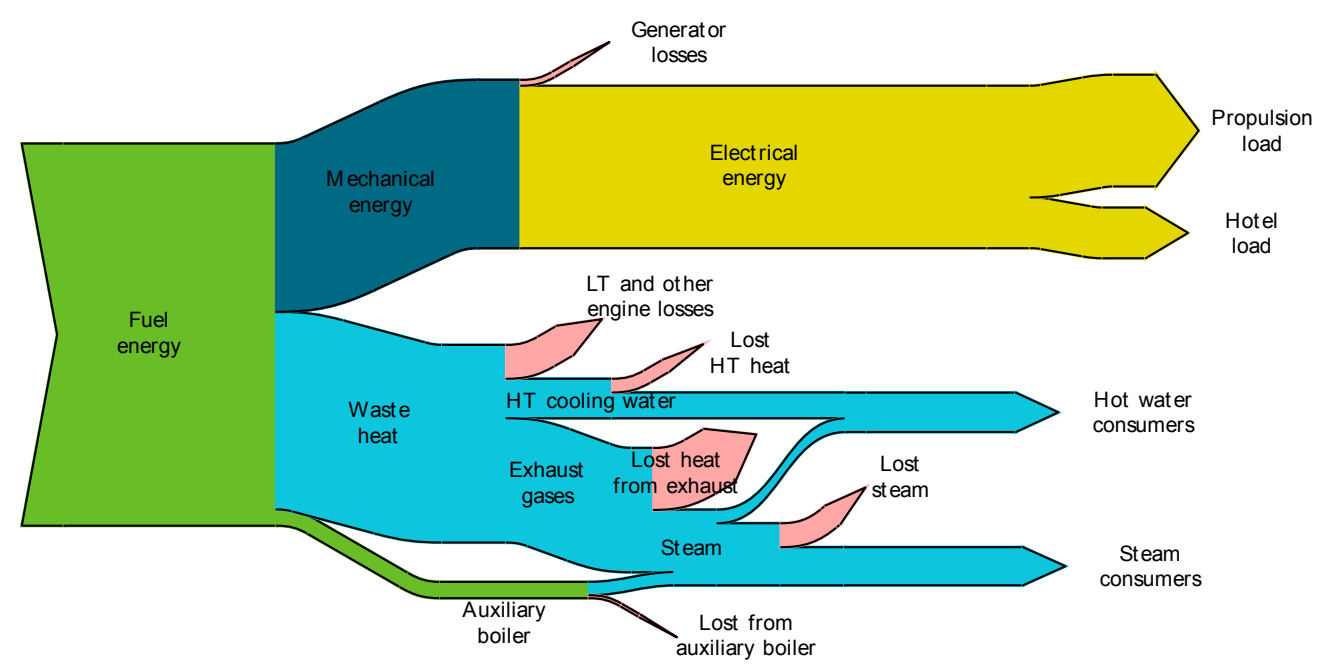

Figure 1: A simplified energy distribution of a cruise ship.

In this study, the efficient utilization of the excess steam heat into additional electricity production is investigated and analyzed. Two waste heat recovery technologies are compared in this study, first is a small-scale radial outflow type of steam turbine, that can directly utilize the steam flow for electricity production, and second is a combination of a steam turbine and a low temperature ORC. If part of the electricity demand onboard can be produced from the excess steam heat, the ship could be operated with correspondingly lower engine power, that will directly lead to reductions in fuel costs and emissions to the atmosphere. The novelty and main objective of this study is to thoroughly investigate the potential of increasing the energy efficiency of modern cruise ships by utilizing the excess steam flow into additional electricity production by using small-scale and high rotational speed steam turbine and a combination of steam turbine and ORC system. In this paper, the optimal sizing of the steam turbine system and the energy production potential with different operational conditions are investigated and the main factors affecting on the WHR energy production are discussed and highlighted.

\section{Case ships and studied WHR systems}

In this section, the information on the selected case ships and their heat balances are presented first. Second, the investigated steam turbine system is described in detail. Third, the low temperature ORC system utilizing the steam turbine condenser heat is presented. 
Table 1: Ship steam values and engine size.

\begin{tabular}{ccc}
\hline \hline & Case ship 1 & Case ship 2 \\
Number of engines & 4 & 6 \\
Max engine power, MW & 73.2 & 81.6 \\
Steam temperature, ${ }^{\circ} \mathrm{C}$ & 330 & 280 \\
Steam pressure, bar(a) & 8 & 9 \\
\hline
\end{tabular}

\subsection{Operational profiles and heat balances of the studied cruise ships}

Two case ships were selected for the study based on the operational profiles and sufficient amount of excess steam available for the studied steam turbine system. The information on the operational profiles and heat balances were gained from marine industry companies. The total engine capacity of the studied ships and the steam values from the steam boilers are presented in Table1. In the analysis, both the studied ships have boilers capable of producing steam at slightly superheated state and steam pressure levels of 8 bar(a) and 9 bar(a). The total installed engine capacity is slightly higher in Ship 2 when compared to engine capacity of Ship 1.

From the studied cruise ships the Ship 1 is running a single itinerary during the whole year while the Ship 2 is operated at four different itineraries during the year. The annual operational times of the Ship 1 and Ship 2 with different cruising speeds are presented in Figure 2a and b. The Ship 1 operates approximately equal time at four different operational speeds an spends about $40 \%$ of the time at harbor, while the Ship 2 has larger variations in it's operational profile. In the Figure $2 a$ and $b$ the time that in where there is no speed indicated means the corresponding time is spent in the harbor.
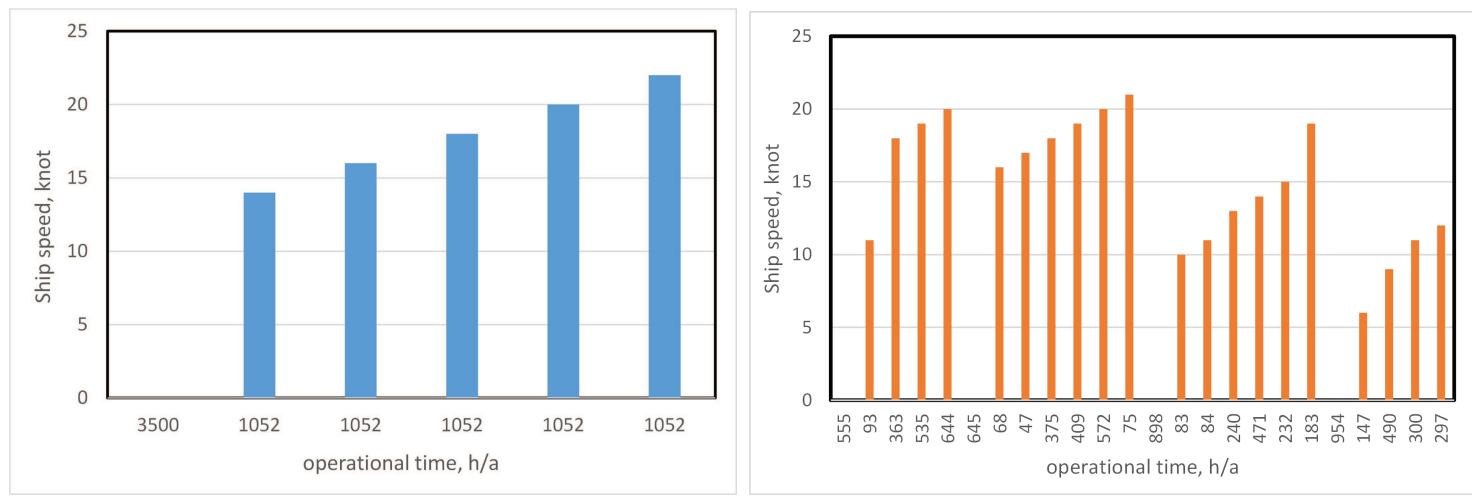

Figure 2: Ship speed and annual operational time of Ship 1 (a) and Ship 2 (b).

At different operational conditions the ship exhaust boilers produce more steam than can be consumed 
by the onboard heat consumers. The amount of excess steam for the corresponding operational points are presented in Figure3a and 3b. The excess steam thermal power is defined as the thermal power of the steam that is left after the amount of steam for the heat consumers has been taken into account. The maximum amount of excess steam power are in the order of magnitude of $9000 \mathrm{~kW}$ to $10000 \mathrm{~kW}$ in both ships whereas during the stays at harbor the exhaust steam boilers can not produce all the heat needed for heating, but instead auxiliary boilers have to be operated in order to fulfill the heat demand onboard. Thus, during the stays at harbor there is no power production potential for the investigated WHR devices.
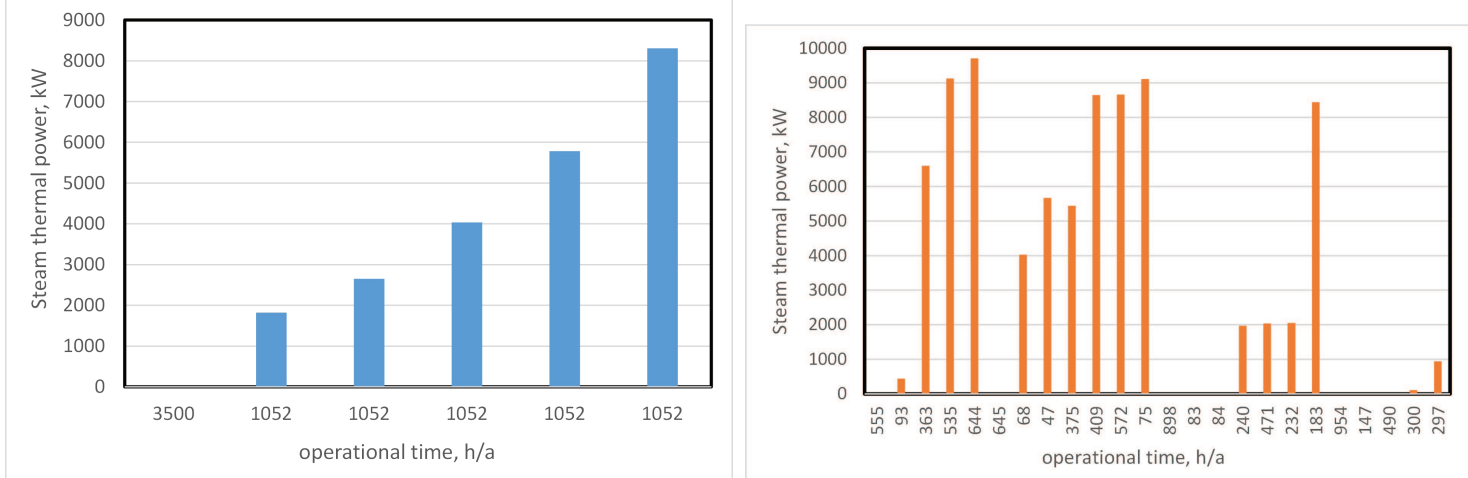

Figure 3: Heat power of excess steam during yearly operation in Ship 1 (a) and Ship 2. (b)

\subsection{Steam turbine system}

A simplified flow diagram of the studied steam turbine process is presented in Figure 4. The excess steam from the steam boilers is expanded through the steam turbine which is connected to a generator and produces additional electric power. After the turbine, the low pressure steam is condensed into liquid by removing the heat in the condenser to the condenser cooling fluid.

In small scale (maximum power of few MW) steam turbine applications, it is challenging to reach high peak turbine efficiencies. This performance degradation is mainly due to two reasons. The first characteristic problem, which is due to relatively low steam flow and high rotational speed, is related to very small blade heights especially in the first turbine stage and thus rapidly increasing secondary losses in turbine blading or the requirement for partial admission. The second reason is related to high pressure ratios, which can lead into supersonic flow velocities and therefore into increased aerodynamic losses. To overcome the latter challenge, a multi-stage turbine can be a solution as the expansion is divided into several stages. In axial flow configuration it increases the turbine length and causes challenges to rotordynamics. However, with radial outflow turbine design the multi-stage turbine can be made relatively compact in physical size in order to minimize the shaft length. Additionally, a partial admission design can be avoided due to comparatively low turbine inlet radius. This turbine type has also increasing power from first to last stage, and when the turbine blade height also increases along the flow direction the secondary losses become less dominating. 


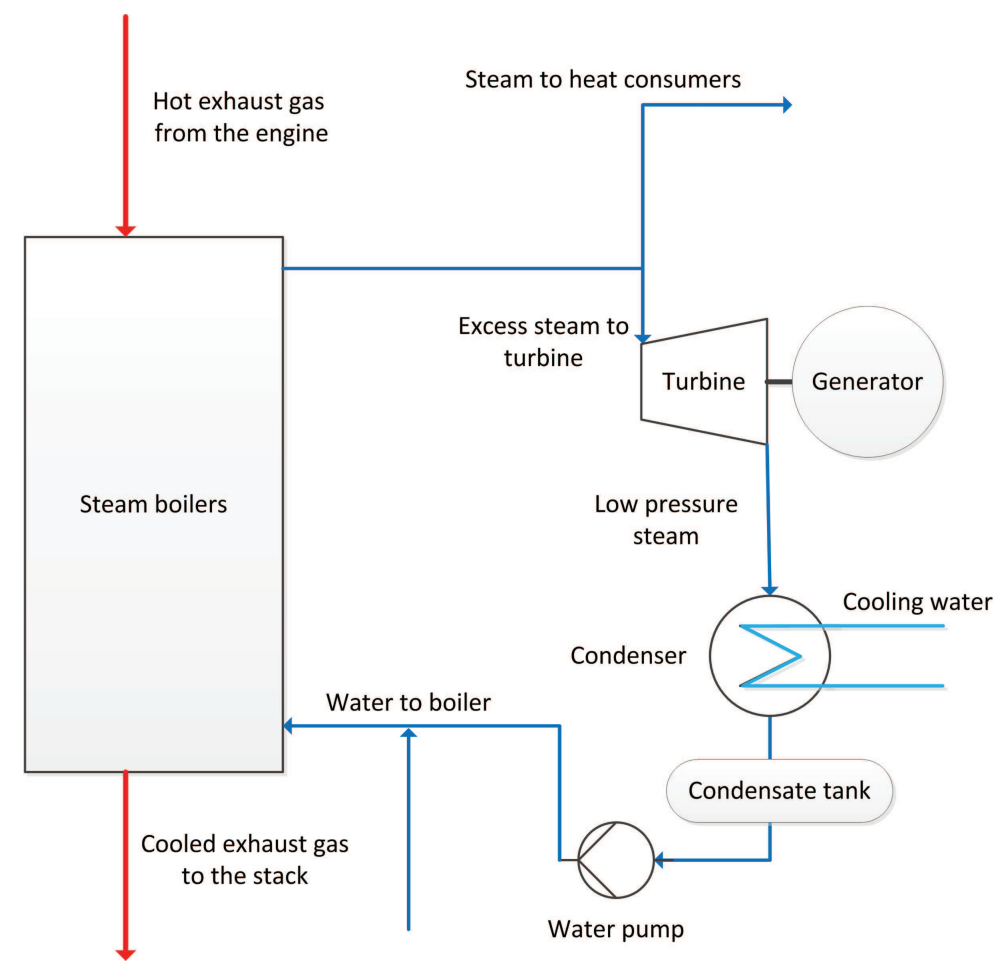

Figure 4: Simplified process diagram of the studied steam turbine system utilizing the excess steam from the steam boilers.

As a result, the high power stages operate with relatively good efficiency and it affects the overall turbine efficiency positively as well. Due to these reasons, the expected peak performance is above the ones of the competing conventional supersonic single stage impulse turbines.

Alongside with the high turbine efficiency at the design point, it is important that the turbine can be operated efficiently at different operational conditions. It has been suggested that multistage radial outflow steam turbine can reach good off-design performance in a wide range off operational points [27]. This suggested off-design behavior is also visible in radial outflow turbine cascade as a practically negligible influence of incidence into averaged spanwise blade outlet flow distribution [28]. Additionally, in the paper of Leino et al. [29] it was estimated that multistage radial outflow steam turbines can have good offdesign performance in about 0.5-2 MW steam turbine applications, when compared to axial turbines with converging-diverging blade shapes, which corresponds well with the steam turbine power range that is investigated in this paper. Radial outflow turbines have been investigated also for ORC applications and several benefits of using this type of turbines have been identified [30]. Thus, in this study radial outflow type of steam turbine was considered as the most suitable turbine type for the studied system. In the steam turbine calculations and analysis, a 1 MW 4-stage radial outflow turbine is used as the design reference [31]. The picture of the reference turbine rotor having four turbine stages and the turbogenerator system, including the electric generator, is presented in Figure 5. The turbine is a two-sided symmetrical design 
Table 2: Reference turbine design values.

\begin{tabular}{cc}
\hline \hline Power output, MW & 1.0 \\
Design isentropic efficiency, $\%$ & $80-83$ \\
Rotational speed, rpm & 12500 \\
Steam mass flow, $\mathrm{kg} / \mathrm{s}$ & 2.44 \\
Turbine inlet temperature, ${ }^{o} \mathrm{C}$ & 330 \\
Turbine inlet pressure, bar(a) & 10 \\
Turbine outlet pressure, bar(a) & 1 \\
Specific speed, - & 0.11 \\
Specific diameter, - & 10.2 \\
\hline
\end{tabular}

where the upper and lower parts of the turbine rotor produce the same amount of power and simultaneously the axial thrust is compensated. It is, however, also possible to design such a turbine as one sided, in where the turbine blades are only on one side of the rotor wheel and the main constructional difference when compared to the two sided design is the requirement for additional axial thrust balancing. This design is suitable for cases where the turbine blade heights become otherwise unfeasible small, for example due to high turbine inlet pressure or low power level. The main design parameters of the reference turbine are presented in Table 2.

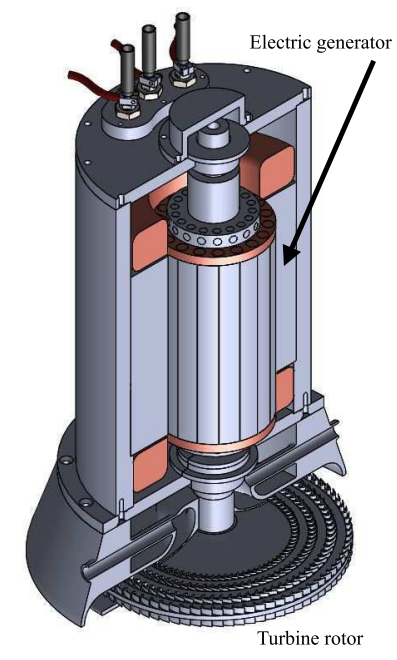

Figure 5: Four stage $1 \mathrm{MW}$-scale radial outflow steam turbine and the electric generator. 
The studied turbogenerator system has the turbine and the generator assembled on single shaft and the electricity is fed to the ship electric grid by using a frequency converter. This arrangement also allows to control the turbine and generator rotational speed for achieving optimal turbine efficiency at wide range of different operational conditions. The high rotational speed of the turbine wheel and generator also makes the turbogenerator structure as more compact when compared to more conventional turbine technology equipped with a gear box. In the evaluation of the steam turbine electric power output, a generator efficiency of $95 \%$ was used which corresponds to the efficiency level of modern high speed generators [32]. It must be borne in mind that the electrical generator design in the case of high-speed drive train is closely coupled to the turbine design, that is, the main input values for the electrical machine design are the turbine power and it's rotational speed range. Therefore, the electrical machine utilized as a generator must be designed case by case to obtain maximum electrical efficiency of the system.

No pressure or heat losses in the piping between the boilers and the steam turbine were taken into account in the analysis. It is also estimated in the analysis that the steam pressure and temperature at the steam turbine inlet can be remained relatively constant at different operational points by the boiler control.

\subsection{Low temperature $O R C$}

The combination of steam turbine and low temperature ORC is also investigated in this study. In this configuration, the low temperature ORC system utilizes the condenser heat of the steam turbine cycle. The investigation was carried out for the case in where the steam turbine condensation temperature is $100{ }^{\circ} \mathrm{C}$, resulting in condenser cooling fluid temperatures high enough for the ORC system to be able to recover the condenser heat. The studied ORC system and it's connection to the steam turbine system is presented in Figure 6. In the studied system there is separate heat transfer circuit between the steam turbine condenser and the ORC system, which condensates the steam and transfers the condensation heat to the working fluid in the ORC system evaporator.

It has been shown that the selection of the working fluid has a significant impact on the ORC system component design and cycle performance $[12,33,34,35]$. In this study the ORC analysis was carried out by using R245fa as the working fluid. R245fa is a widely used refrigerant in low temperature ORC applications (e.g. [36, 37, 38] and in addition R245fa was evaluated as suitable fluid for the analysis since it is non-flammable and non-toxic, which are necessity design requirements when considering the strict safety requirements for fluids that can be approved to be used in cruise ships.

\section{Numerical methods and model validation}

The numerical methods for the steam turbine analysis, ORC analysis and code validation are presented in this section. 


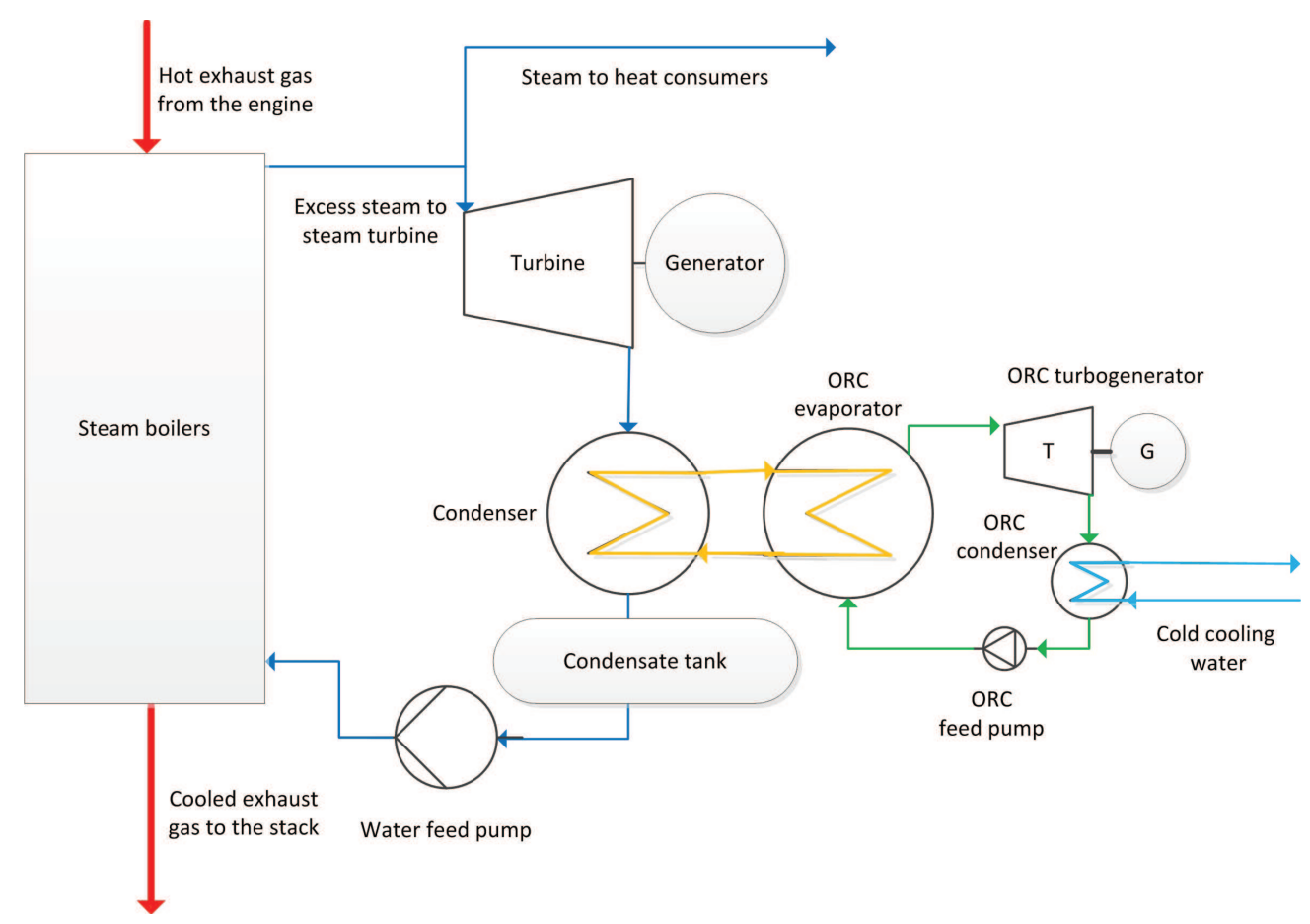

Figure 6: Simplified process diagram of the studied steam turbine system connected to low temperature ORC process.

\subsection{Steam turbine}

The steam turbine simulations were carried out by using the calculation principles of a steam Rankine cycles. The thermodynamic property table IF97 of steam properties was used for calculating the steam thermodynamic state at the turbine inlet and outlet and at the condenser outlet. The excess steam flow rate, pressure and temperature were given as input for each operational condition according to the thermal balance of the ship. The turbine outlet enthalpy was solved from the definition of turbine isentropic efficiency as,

$$
h_{\mathrm{t}, \text { out }}=h_{\mathrm{t}, \text { in }}-\eta\left(h_{\mathrm{t}, \text { in }}-h_{\mathrm{t}, \mathrm{out}, \mathrm{s}}\right) .
$$

The mechanical power of the turbine was calculated as

$$
P_{\mathrm{t}}=q_{\mathrm{m}, \text { steam }}\left(h_{\mathrm{t}, \text { in }}-h_{\mathrm{t}, \text { out }}\right) \text {. }
$$

In the studied ships, the steam turbine is operated at different off-design conditions and thus, it is important to take into account and evaluate the steam turbine efficiency at off-design conditions, in order to have a realistic evaluation on the energy production potential under the ship operational profile. This was done by using the turbine power correction factor at off-design conditions. The turbine power at off-design operational conditions was defined as, 


$$
P_{\mathrm{t}, \text { off }}=\varsigma q_{\mathrm{m}, \text { steam }}\left(h_{\mathrm{t}, \text { in }}-h_{\mathrm{t}, \text { out }}\right),
$$

in which the excess steam mass flow at the corresponding operation point is used and the turbine outlet enthalpy is calculated by using the turbine design isentropic efficiency. The turbine off-design performance was evaluated based on the information available in references $[27,28,39]$ that are presenting and discussing the off-design performance characteristics of small-scale radial outflow and axial steam turbines. The offdesign performance prediction was based on off-design performance curve presented in [27] that is based on experimental work for a radial outflow turbine. This curve was slightly modified based on the information available in references $[28,39]$ as the studied turbine system have more turbine stages and lower power scale when compared to the turbine studied in [27]. In addition, the turbine off-design performance curve was modified based on the information gained in a project in where a $1 \mathrm{MW}$ steam turbine-generator based on radial outflow turbine was designed and constructed at Lappeenranta University of Technology and Saimaa University of Applied Sciences [31]. It should be highlighted that the used turbine off-design performance curve can contain some inaccuracies, but on the other hand, a more accurate turbine off-design performance prediction would require more experimental work and flow simulations for different radial outflow turbine geometries. It was also estimated that the possible inaccuracies in the implemented turbine off-design performance prediction affects at the maximum of less than $10 \%$ on the annual energy production. The steam turbine off-design correction factor curves are presented in Fig 7.

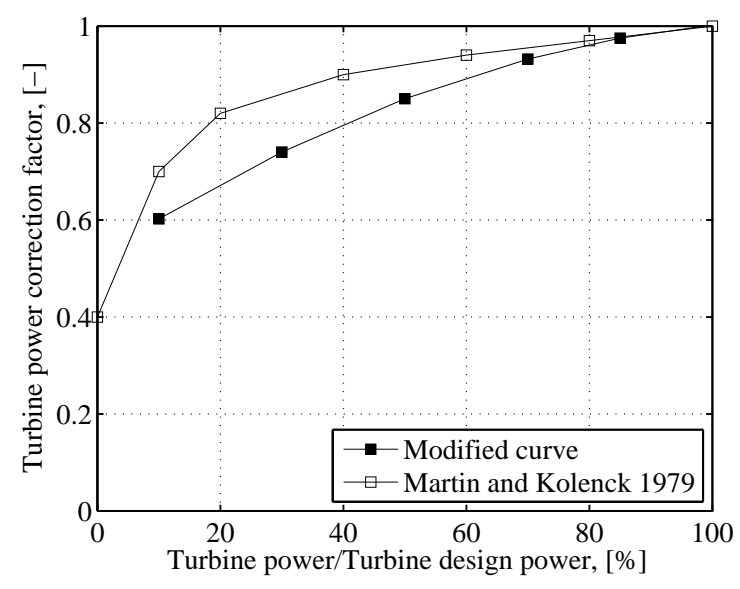

Figure 7: Turbine power correction factor for predicting the turbine performance at different off-design conditions.

According to [39] multistage steam turbines have limits for the operation when the steam flow is significantly lower than the design steam flow rate. Thus, in addition to off-design performance corrections of the steam turbine, the lowest operational power limit for the steam turbine was implemented in the analysis. The lower power limit was defined as the ratio of the simulated turbine power at different operational conditions and steam turbine design power: 


$$
x=\frac{P_{\mathrm{t}, \mathrm{off}}}{P_{\mathrm{t}}} .
$$

In addition, a higher power limit for the turbine power was included in the analysis that restricts the maximum turbine power output to be equal to the steam turbine design power.

The annual electric energy output with different turbine design powers was defined as the sum of the energy produced at different operational conditions. The electric energy was calculated as

$$
E_{\mathrm{a}}=\sum_{n=1}^{a} P_{\mathrm{t}} * t_{\mathrm{n}}+\sum_{n=1}^{b} P_{\mathrm{t}, \mathrm{off}, \mathrm{n}} * t_{\mathrm{n}},
$$

in where points (1..a) the steam turbine is running at the design power and in points (1..b)the steam turbine is running at different off-design conditions.

The turbine capacity factor was also calculated for different cases. The capacity factor indicates the ratio between the average turbine power during the ship operation and the turbine design power, and is defined as,

$$
C=\frac{E_{\mathrm{a}} / 8760 h}{P_{\mathrm{t}}} .
$$

The optimal turbine rotational speed and turbine diameter were evaluated for different operational conditions and steam turbine design powers by using the non-dimensional design parameters specific speed and specific diameter, as well as the design information of the $1 \mathrm{MW}$ reference steam turbine[31]. These parameters can be used for evaluating the optimal rotational speed and turbine diameter for different operational conditions, turbine sizes and turbine types. The non-dimensional design parameters can be also used for the preliminary turbine efficiency prediction by knowing the turbine efficiency of a similar type of turbine, designed for different operational conditions, as the use of non-dimensional design parameters results in similar turbine design in terms of turbine flow mechanisms[40]. The specific speed can be defined as,

$$
N_{s}=\frac{\omega q_{v}{ }^{0.5}}{\Delta h_{s}{ }^{0.75}}
$$

and the specific diameter can be defined as

$$
D_{s}=\frac{d \Delta h_{s}^{0.25}}{q_{v}^{0.5}} .
$$

The values for specific speed and specific diameter were selected based on the reference turbine design and the optimal rotational speed and diameter were calculated for different turbine designs. Additionally, the designed turbines were compared to available preliminary designs at different electric power levels to verify the results. 
Table 3: Summary of ORC system input parameters.

\begin{tabular}{c}
\hline \hline Working fluid, R245fa \\
Expander efficiency, $75 \%$ \\
Expander inlet temperature, $80{ }^{\circ} \mathrm{C}$ \\
Condensing temperature, $30{ }^{\circ} \mathrm{C}$ \\
Generator efficiency, $90 \%$ \\
Degree of recuperation, 0.6 \\
Feed pump efficiency, $80 \%$ \\
Feed pump motor efficiency $85 \%$ \\
\hline
\end{tabular}

\subsection{ORC model}

The ORC cycle model uses commercial thermodynamic library Refprop[41] for calculating the fluid thermodynamic state at different process nodes. The similar model has been used previously in e.g. [12, 42] and the thermodynamic model is described in detail in these references. The model validation is also presented in the following section. The cycle component efficiencies and parameters that were used in the LT ORC system analysis are summarized in Table 3. The component efficiencies for the ORC analysis were selected based on information given in[34, 37, 42]. The evaporation temperature of $80{ }^{\circ} \mathrm{C}$ was used since it was assumed to ensure sufficient temperature differences between the condensing steam and the evaporating working fluid. The condensing temperature of $30{ }^{\circ} \mathrm{C}$ was used for the $\mathrm{ORC}$ condenser by assuming $20{ }^{\circ} \mathrm{C}$ sea water to be available for the ORC system condenser cooling. The effect of the condensing temperature on the ORC cycle efficiency is also investigated in the sensitivity analysis. In the study of $\mathrm{Hu}$ et al.[43] it was studied that the ORC system cycle efficiency can be remained relatively constant at a wide range of heat input conditions and can even slightly increase at low heat rate conditions by using suitable control strategy for the system. Thus, it was assumed in the ORC system analysis that the ORC efficiency can be remained as constant under the studied heat source conditions, in order to simplify the analysis. However, it should be noted that the off-design performance characteristics of such a system are highly dependent on the system architecture, expander type and scale, heat exchangers and applied control methods.

\subsection{Code validation}

The steam turbine model was validated against data available for a small-scale WHR steam turbine presented in [44] including experimental data on the steam turbine system performance. In the validation and comparison the turbine inlet pressure and temperature, flow rate, turbine outlet pressure, isentropic 
efficiency of the turbine and generator efficiency were set to the same values as were used in[44]. The turbine inlet enthalpy and power output to grid was calculated and the results were compared against the results presented in ref[44]. Based on the comparison, the steam turbine model used in this study and the results presented in [44] have good agreement in the power output estimation which gives a good foundation for the numerical steam turbine analysis presented in this paper.

Table 4: Steam turbine analysis tool validation and comparison to reference[44].

\begin{tabular}{ccc}
\hline \hline & Steam turbine model & Ref [44] \\
Turbine inlet enthalpy, kJ/kg & 3321.6 & 3322 \\
Electric power output to grid, kW & 40.2 & $>40$ \\
\hline
\end{tabular}

The ORC thermodynamic model was validated and the results were compared against the ORC system design results of Kang [37] that have been further experimentally validated. The cycle has the operational conditions close to the ones adopted in this study for the low temperature ORC investigations. The R245fa flow rate of $1.58 \mathrm{~kg} / \mathrm{s}$ and turbine efficiency of $75 \%$ were used as in [37]. In addition, the cycle turbine inlet temperature and pressure, as well as outlet pressure were set to the same values as in [37]. The heat and pressure losses in the cycle as well as feed pump power consumption were neglected and the simulated turbine power and cycle efficiencies were compared. The results of the ORC model validation are presented in Table 5. The validation shows that the prediction on turbine power and cycle efficiency have both good agreement between the thermodynamic analysis tool and Ref[37] which gives a good foundation on the accuracy of the results obtained in the numerical ORC analysis.

Table 5: ORC thermodynamic analysis tool validation and comparison to reference[37].

\begin{tabular}{lccc}
\hline \hline & Thermodynamic model & Ref [37] & dev, \% \\
Turbine power, kW & 31 & 30 & $3.3 \%$ \\
Cycle efficiency, $\%$ & 8.78 & 8.76 & $0.2 \%$ \\
\hline
\end{tabular}

\section{Results and discussion}

First, the effect of turbine design efficiency, lower operational power limit of the steam turbine system and condensing conditions are investigated. Second, the results of annual electric energy production potential 
with the steam turbine system by using the operational conditions of Ship1 and Ship2 and different steam turbine design powers are investigated. Third, the results of energy production potential by using a combination of steam turbine and low temperature ORC system are presented. Finally, the steam turbine optimal rotational speed and diameter are investigated with different power scales and condensing conditions.

\subsection{Sensitivity analysis on the effect of turbine design efficiency and lower operational power limit on energy production}

An example of the effect of steam turbine design efficiency and lower operational power limit of the steam turbine on the annual energy production are presented in Fig $8 \mathrm{a}$ and b. These results were obtained by using the operational profile of Ship 2 and by using a condensing temperature of $80^{\circ} \mathrm{C}$ in the simulation. The results are presented for Ship 2 only for readers' convenience since Ship 1 predicts generally similar behavior. In Figure $8 \mathrm{a}$ the turbine design isentropic efficiency $\eta_{\mathrm{t}}$ was varied between $70 \%$ to $85 \%$ and in figure $8 \mathrm{~b} x$ was varied between $0 \%$ to $30 \%$ and in. Based on the analysis both the turbine design efficiency and the turbine capability to utilize the low steam flow conditions have a significant impact on the annual electric energy production. The differences in the steam turbine energy production are more pronounced at high steam turbine design powers when comparing a turbine with high isentropic efficiency and a lower isentropic efficiency. For the studied conditions, the maximum deviation is about $700 \mathrm{MWh} / \mathrm{a}$ when comparing turbines with the same design power and having the design efficiencies of $85 \%$ and $75 \%$. The maximum deviations in the energy production is about $200 \mathrm{MWh} / \mathrm{a}$ when comparing the results for turbines having the equal design power and efficiency, but different lower operational limit.
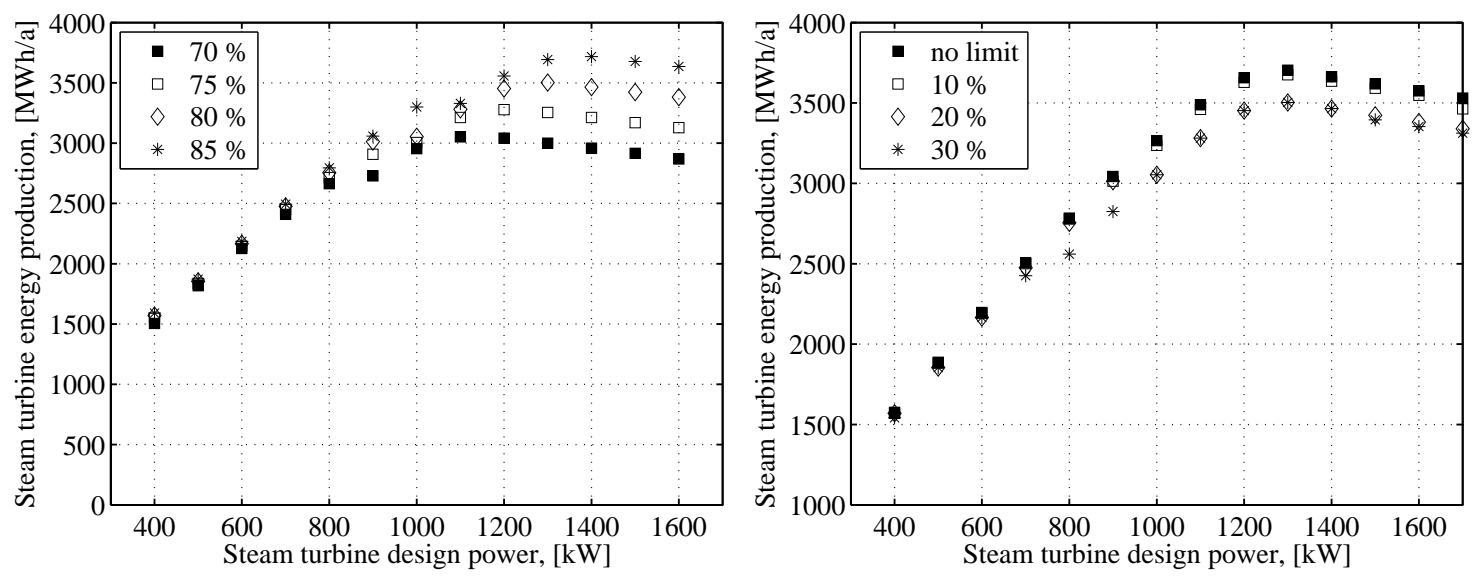

Figure 8: The effect of steam turbine design efficiency (a) and effect of lower operational power limit of the steam turbine (b) on annual energy production. The simulations were carried out by using the operational profile of Ship2 and condensing temperature of $80^{\circ} \mathrm{C}$. 


\subsection{Steam turbine energy production and optimal design power}

The steam turbine isentropic efficiency of $80 \%$ at the turbine design operational conditions was used in the later analysis as it was evaluated as a realistic value to be achieved for about $500 \mathrm{~kW}$ to $2 \mathrm{MW}$ scale steam turbines [31]. In addition, the lowest turbine operation power limit of 0.2 was used for the steam turbine in the following analysis. The condensing temperature also highly affects on the steam turbine design and performance. Despite the fact that the use of low condensing temperature increases the power production potential, lower condensing temperatures than $40{ }^{\circ} \mathrm{C}$ were neglected in this study, because the use of lower condensing temperatures would lead to high wetness fractions at the turbine outlet which was estimated to limit the technical lifetime of this type of steam turbines. In addition, with low condensing temperatures the expansion ratio of the turbine would increase significantly and would require complex turbine structures with a large number of stages and large increase in the turbine flow passage area along the expansion. Thus, the following energy production simulations were carried out by using four different condensing temperatures of $40{ }^{\circ} \mathrm{C}, 60^{\circ} \mathrm{C}, 80{ }^{\circ} \mathrm{C}$, and $100{ }^{\circ} \mathrm{C}$. The effect of different condensing temperatures on the expansion ratio over the steam turbine and the expansion process on a temperature-entropy plane are presented in Figures $9 \mathrm{a}$ and $\mathrm{b}$.
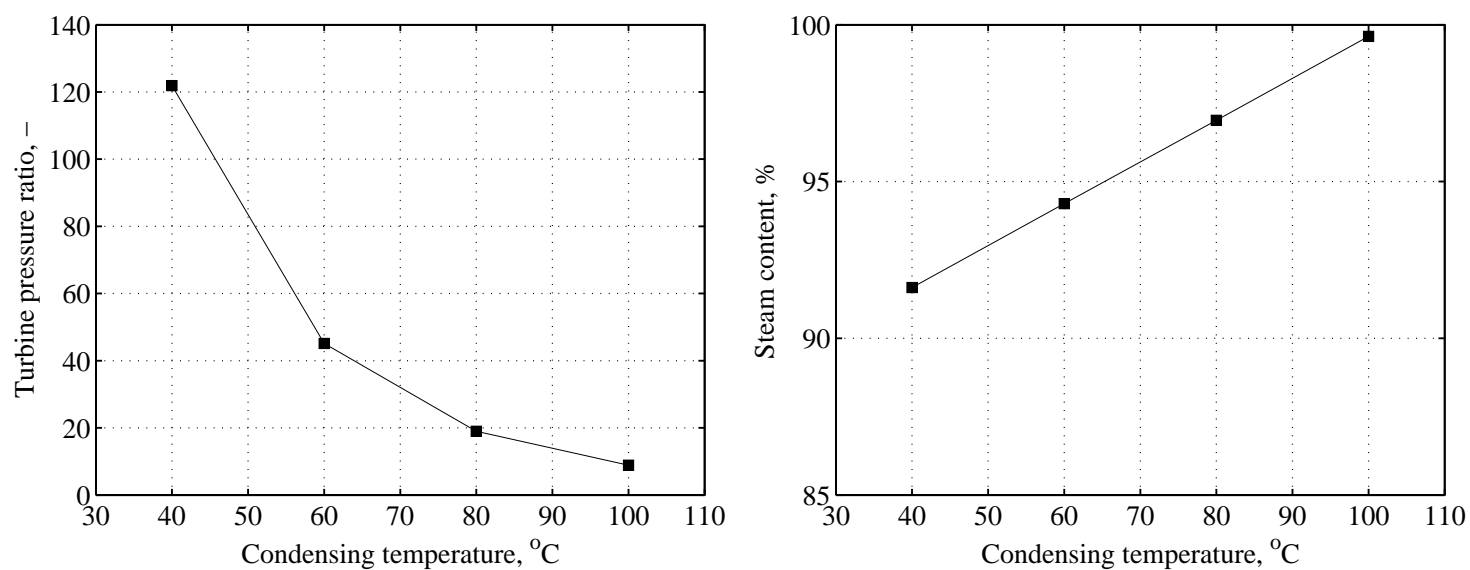

Figure 9: Turbine pressure ratio (a), and steam content at the turbine outlet (b) with different condensing conditions. The steam values of Ship 2 were used as the turbine inlet conditions.

The simulation results on electric energy production potential in Ship1 and Ship2 are presented in Figure10a and b. The highest energy production potential of over $5310 \mathrm{MWh} / \mathrm{a}$ was simulated in Ship 2 and $3920 \mathrm{MWh} / \mathrm{a}$ in the Ship 1. The simulated steam turbine energy production is in the order of magnitude of $1 \%$ to $1.5 \%$ of the total energy produced by the ship engines. For achieving the highest energy outputs with the steam turbine a low condensing temperature and pressure has to be used. With the highest studied condensing temperature of $100{ }^{\circ} \mathrm{C}$ and condensation pressure of 1 bar the maximum energy production of $2290 \mathrm{MWh} / \mathrm{a}$ was simulated in Ship1 and $2850 \mathrm{MWh} / \mathrm{a}$ in Ship 2. The condensing temperature has 
a significant impact not only on the energy production but it also heavily affects on the optimal sizing of the steam turbine system. At the lowest studied condensing temperatures the maximum annual energy production is achieved with a steam turbine size of 1200 - $1500 \mathrm{~kW}$ in Ship 1 and with about 1500 - $2000 \mathrm{~kW}$ steam turbine size in Ship 2, whereas with the higher condensing temperatures, the maximum simulated energy production was achieved with significantly lower turbine design power of close to $1000 \mathrm{~kW}$. The discontinuities in the plots presented in Figure10 a and b can be explained by the implemented limit of the lowest power level $(\mathrm{x})$ of the steam turbine which results in that as the steam turbine design power is increased, some of the operational conditions having low steam flow rates cannot be utilized.
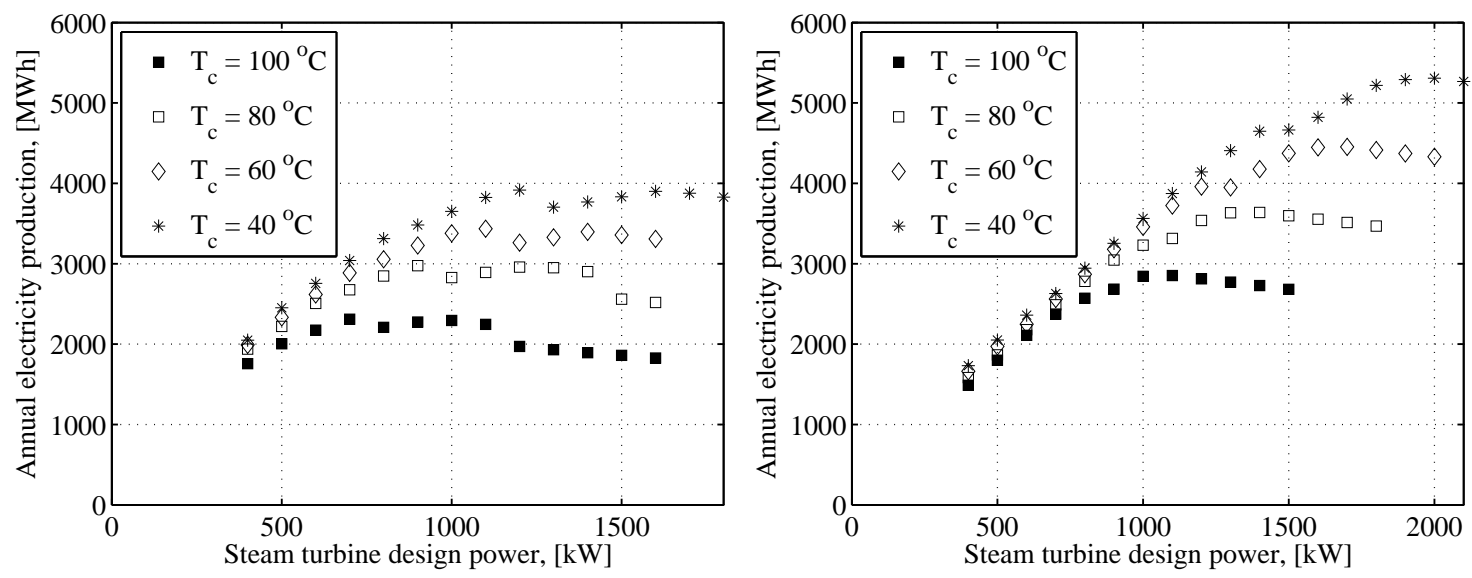

Figure 10: The effect of steam turbine design power on the annual electricity production from the excess steam. (a) is Ship 1 and (b) Ship 2.

As a general remark, if the steam turbine design power is low, the turbine can utilize the low steam flow conditions more effectively when compared to a higher turbine design power. In addition, the use of turbine with high design power leads to low turbine efficiency at low steam flow conditions and even disables the utilization of low steam flow operational conditions, that reduces the annual energy production potential. On the other hand, if the steam turbine design power is low the high excess steam flow conditions can not be as efficiently utilized as with a steam turbine having a higher design power, because the maximum turbine power is limited by the design power that declines the power production at high excess steam heat conditions. The effect of turbine design power on the electric power production and on the electric energy production are highlighted in Figures 11a and b. The steam turbine electric power production as a function of excess steam flow with different turbine design powers is presented in Figure 11a and the steam turbine energy production with steam turbines having the design power of $500 \mathrm{~kW}$ and $1000 \mathrm{~kW}$ in Figure $11 \mathrm{~b}$. These simulations were carried out by using the operational profile of Ship1 and by using the condensing conditions of $100{ }^{\circ} \mathrm{C}$.

The steam turbine capacity factor representing the ratio of the average steam turbine power during the 

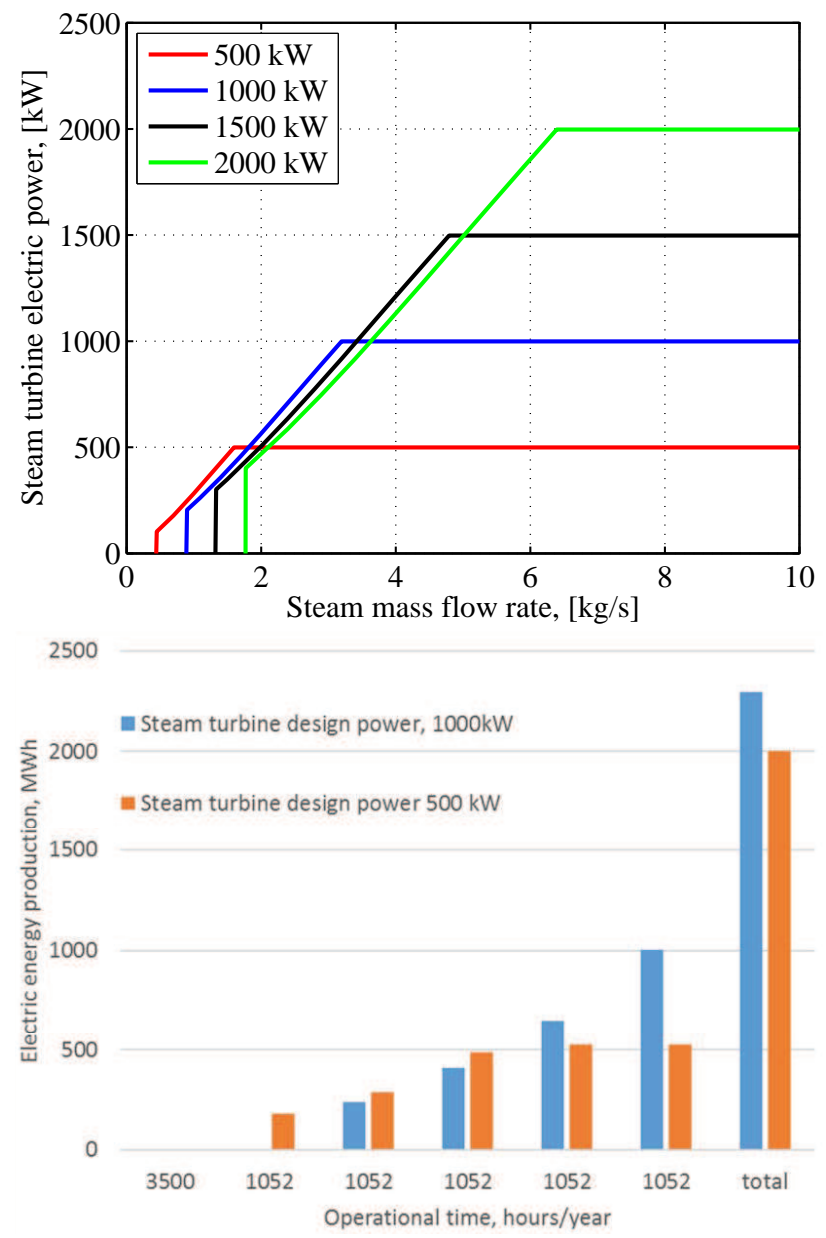

Figure 11: The effect of excess steam mass flow rate on turbine electric power production with different turbine design powers (a) and comparison of annual steam turbine electric energy production with $500 \mathrm{~kW}$ design power and $1000 \mathrm{~kW}$ design power (b). The simulation was performed by using a condensing temperature of $100{ }^{\circ} \mathrm{C}$.

ship operation and the steam turbine design power is presented in Figure 12 for different turbine design powers. The higher the turbine design power, the lower is the capacity factor, meaning that the turbine is operating most of the time at significantly lower power outputs than the design power of the steam turbine is. With the lowest studied steam turbine design powers, relatively high capacity factors, in a range of 40 to $50 \%$, were simulated whereas with the highest studied turbine design powers the simulated capacity factors were significantly low ranging from 15 to $30 \%$. Thus, despite the fact that the highest simulated energy outputs were achieved with turbines having a relatively high design power, selecting the turbine system size only by optimizing the annual energy output can be a non-optimal solution when considering the economic feasibility of the studied steam turbine system, depending on the investment costs of different sized turbines. 

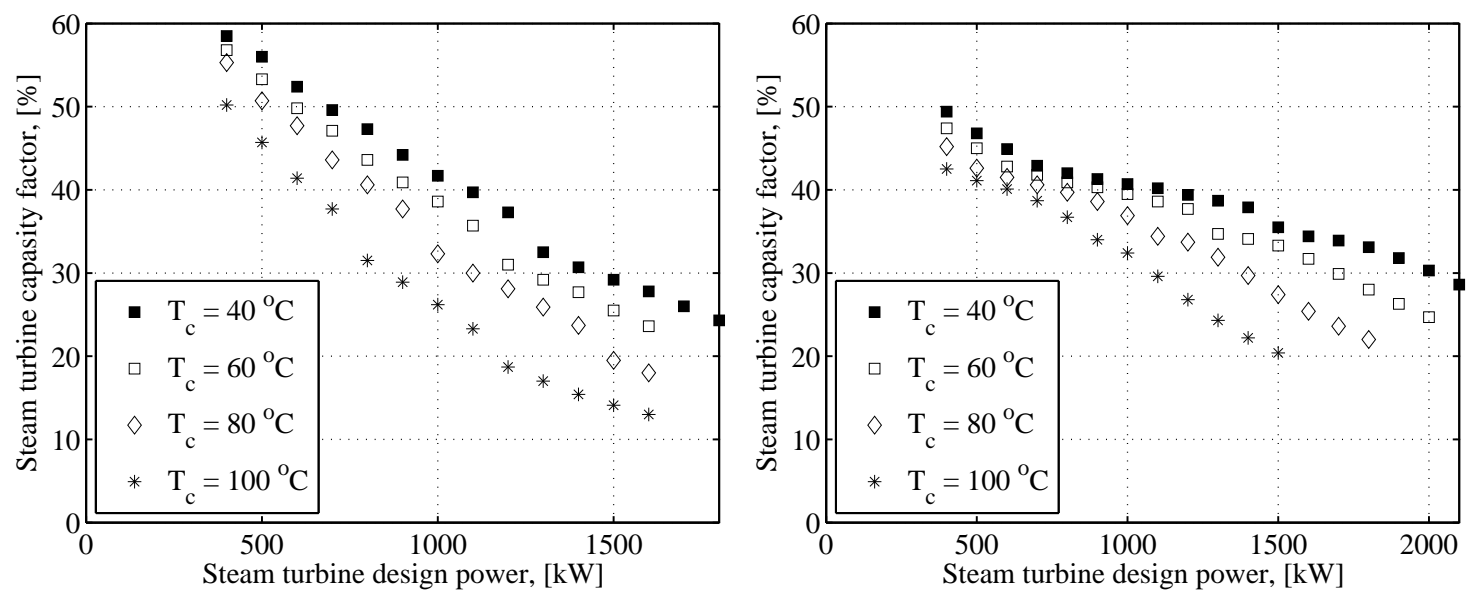

Figure 12: The effect of steam turbine design on the steam turbine capacity factor. (a) is Ship 1 and (b) Ship 2

\subsection{Condenser heat utilization with LT ORC and result summary}

The main results of the energy production of system having a combination of a steam turbine and low temperature ORC are presented in this section. The simulation was carried out for case of steam turbine condensation temperature of $100{ }^{\circ} \mathrm{C}$. The heat input for the ORC equals to the amount of heat that is transferred in the steam turbine condenser to the condenser coolant. The sensitivity of the ORC system efficiency on the condensing conditions and on the expander efficiency were investigated first and the main results of these simulations are presented in Figure 13. The results of the low temperature ORC show that the potential for producing electricity from the low temperature waste heat is highly dependent on the condensing conditions and expander efficiency. This type of system can be considered as an attractive technical option in ships having relatively cold sea water available for the ORC condenser cooling. With low condensing temperature of $20{ }^{\circ} \mathrm{C}$ and high expander efficiency the cycle can reach well over $10 \%$ electric efficiency whereas with higher condensing temperatures and low expander efficiency the ORC electric efficiency can be less than $5 \%$.

The energy production simulations were carried out by using a condensing temperature of $30{ }^{\circ} \mathrm{C}$ that can be reached if the ORC condenser cooling is arranged with about $20^{\circ} \mathrm{C}$ sea water. In addition, expander efficiency of $75 \%$ was used which was evaluated as feasible value for the ORC turbine according to references $[37,34]$. The ORC system reaches the net electric efficiency of $8.3 \%$ under the studied operational conditions. The studied ORC system is illustrated on a temperature-entropy plane in Figure 14 and the simulation results on annual electric power production potential is presented in Figures 15 a and b for Ship1 and Ship2 respectively.

The ORC was simulated to be capable of producing about $2000 \mathrm{MWh} / \mathrm{a}$ electric energy in ship1 and above $2200 \mathrm{MWh} / \mathrm{a}$ in ship2 depending on the steam turbine design power. The combination of steam turbine system and ORC can reach the maximum electric energy production of about $4200 \mathrm{MWh} / \mathrm{a}$ in ship 


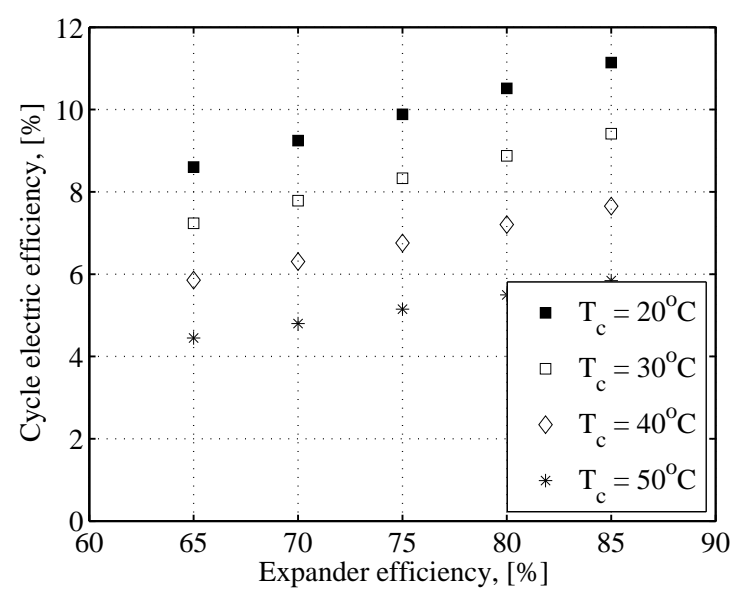

Figure 13: The effect of expander efficiency and condensing temperature on ORC electric efficiency.

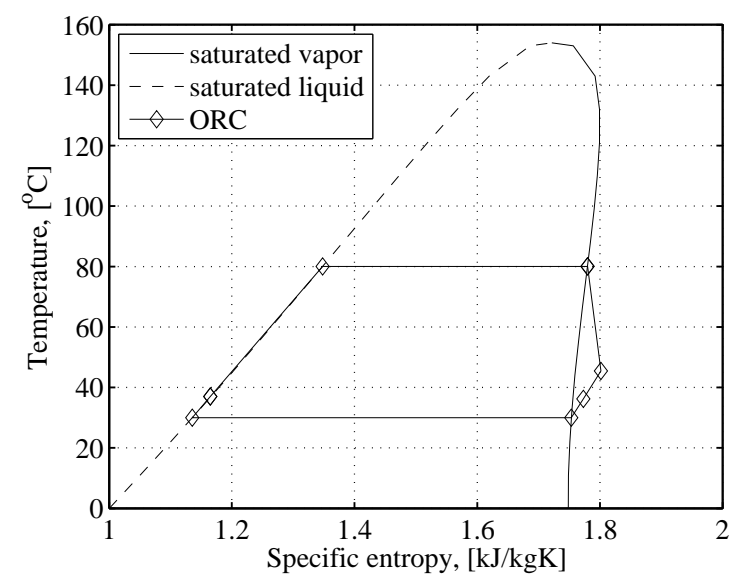

Figure 14: The studied LT ORC system on temperature-entropy plane.

1 and about $5000 \mathrm{MWh} / \mathrm{a}$ in ship 2. These energy production results are relatively close to the results of the steam turbine simulations having the lowest condensation temperature of $40{ }^{\circ} \mathrm{C}$. The combination of steam turbine and $\mathrm{ORC}$ reaches the maximum energy production when the steam turbine design power resulting in the highest annual energy production is selected. Example of the simulated electric power output of steam turbine and ORC are presented at different operational points of Ship1 and Ship2 in Figures16a and b. In these results the steam turbine design power of $1000 \mathrm{~kW}$ was used. The maximum power outputs for the ORC system of about $600 \mathrm{~kW}$ were simulated in Ship1 and slightly above $700 \mathrm{~kW}$ in Ship2. The ORC was simulated to be capable of producing power outputs comparable to the steam turbine power output at the low excess steam conditions. In Ship2 there are few operational points in where the ORC was capable of producing power whereas the steam turbine can not operate due to the insufficient amount of excess steam available for the system. This can be partly explained that no lower operational limit or cycle efficiency 

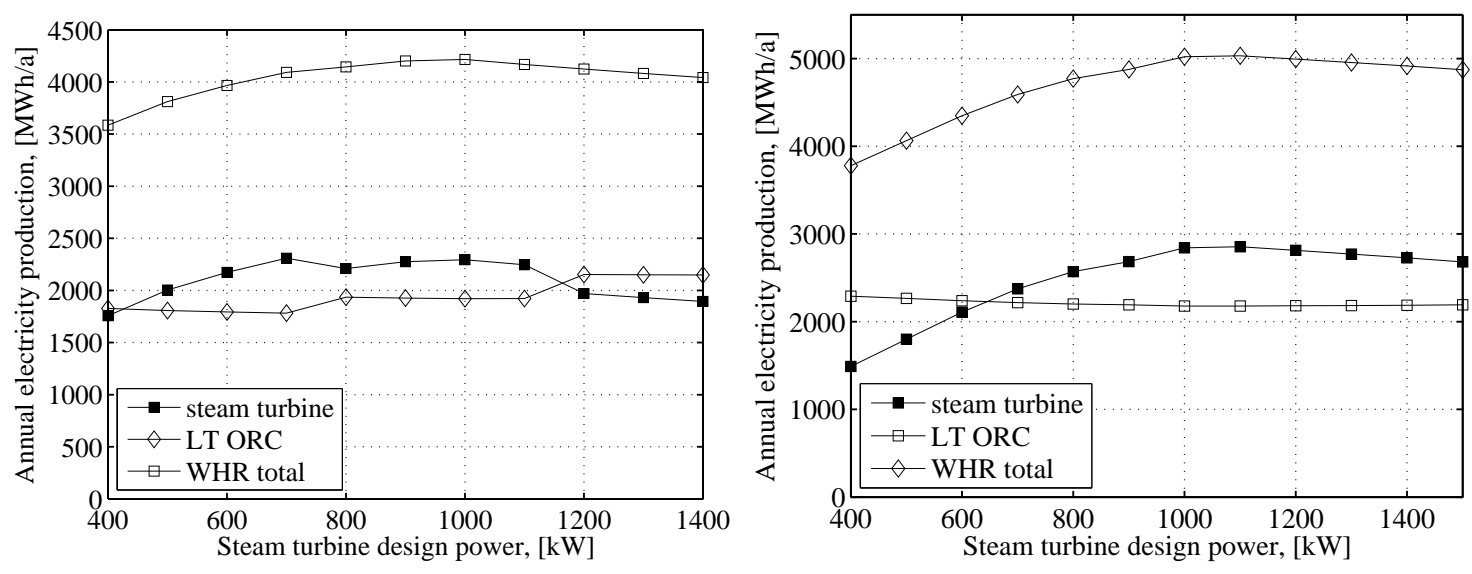

Figure 15: Electric energy production potential with the combination of steam turbine and low temperature ORC in Ship 1 (a) and in Ship 2 (b).

reduction for the ORC system at off-design conditions was taken into account in the analysis. On the other hand, by implementing for example a lower power limit of $20 \%$ for the ORC system and by assuming the ORC design power to be the maximum simulated power output of the ORC systems, the annual energy production is not declined when compared to the presented results in Ship1 and declines only about 30 MWh/a in Ship2.
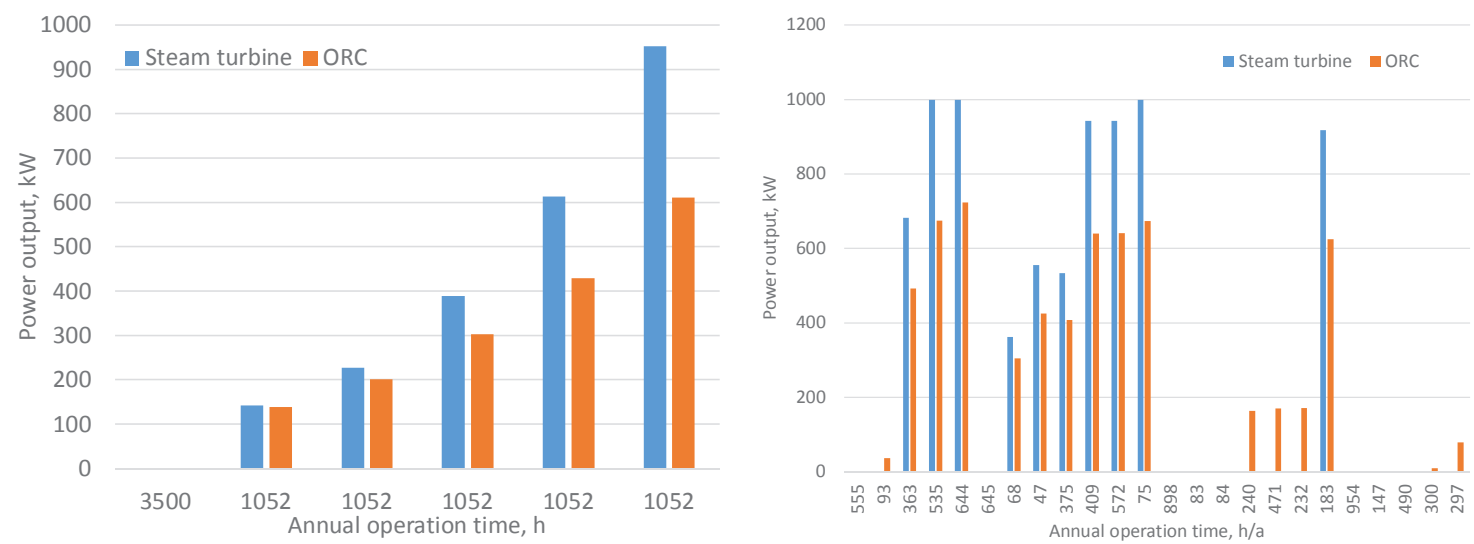

Figure 16: Simulated electric power production with the combination of steam turbine and low temperature ORC in Ship 1 (a) and in Ship 2 (b) at different ship operational conditions.

As a general remark the temperature level of the studied low temperature heat recovery cycle is relatively close to the typical temperature level of the engine cooling cycle, collecting the engine jacket heat and charge air heat. The thermal power of the engine cooling cycle can be as high as about $15 \%$ of the engine fuel power in modern four stroke engines[45] and the results of [26] also showed the high energy production potential from the engine low temperature heat with ORC. Thus, by combining the engine cooling cycle 
heat utilization and steam turbine condenser heat utilization systems in single ORC unit, there is potential for gaining significantly higher fuel consumption reductions and emission reductions, when compared to the excess steam heat utilization only. In addition, despite the fact that the use of the ORC increases the complexity of the WHR system, pressures below the atmospheric pressure can be avoided in the steam turbine system that removes the need for using vacuum systems in the steam turbine condenser and also the risk of steam turbine blade erosion.

The results of the annual energy production and steam turbine design power resulting in the highest energy output for each of the studied cases are summarized in Table 6. The results are presented for both Ship 1 and Ship 2 .

Table 6: Result summary

\begin{tabular}{ccc}
\hline \hline & $E_{a}, \mathrm{MWh}$ & $P_{t}, \mathrm{~kW}$ \\
\hline Ship 1 & & \\
\hline Steam turbine, $\mathrm{T}_{c}=40{ }^{\circ} \mathrm{C}$ & 3920 & 1200 \\
Steam turbine, $\mathrm{T}_{c}=60{ }^{\circ} \mathrm{C}$ & 3440 & 1100 \\
Steam turbine, $\mathrm{T}_{c}=80{ }^{\circ} \mathrm{C}$ & 2980 & 900 \\
Steam turbine, $\mathrm{T}_{c}=100{ }^{\circ} \mathrm{C}$ & 2290 & 1000 \\
Steam turbine and $\mathrm{ORC}$ & 4220 & 1000 \\
\hline Ship 2 & & \\
\hline Steam turbine, $\mathrm{T}_{c}=40{ }^{\circ} \mathrm{C}$ & 5310 & 2000 \\
Steam turbine, $\mathrm{T}_{c}=60{ }^{\circ} \mathrm{C}$ & 4450 & 1700 \\
Steam turbine, $\mathrm{T}_{c}=80{ }^{\circ} \mathrm{C}$ & 3640 & 1400 \\
Steam turbine, $\mathrm{T}_{c}=100{ }^{\circ} \mathrm{C}$ & 2850 & 1100 \\
Steam turbine and $\mathrm{ORC}$ & 5020 & 1100 \\
\hline
\end{tabular}

\subsection{Estimation on steam turbine rotational speed and diameter at different power levels}

The preliminary evaluation of the steam turbine rotational speed and diameter were investigated for 0.5 MW to $2 \mathrm{MW}$ power scale turbines. The turbine optimal rotational speed and the rotor diameter were studied first by using specific speed values ranging from 0.1-0.2 and specific diameter values ranging from 5-10. These ranges were selected based on the results of several turbine designs and were identified as suitable for radial outflow turbines on the studied power scale in the project. The results on the effect of specific speed and specific diameter on the turbine design with a condensing temperature of $100{ }^{\circ} \mathrm{C}$ and 
having a two sided rotor design are presented in Figures 17. By selecting a higher specific speed the turbine becomes more fast rotating when compared to a turbine designed with a lower specific speed. By selecting a higher specific diameter for the turbine design, the turbine rotor is larger when compared to turbine designs with lower specific diameter. The steam turbine design power also highly affects on the turbine optimal rotational speed and diameter.
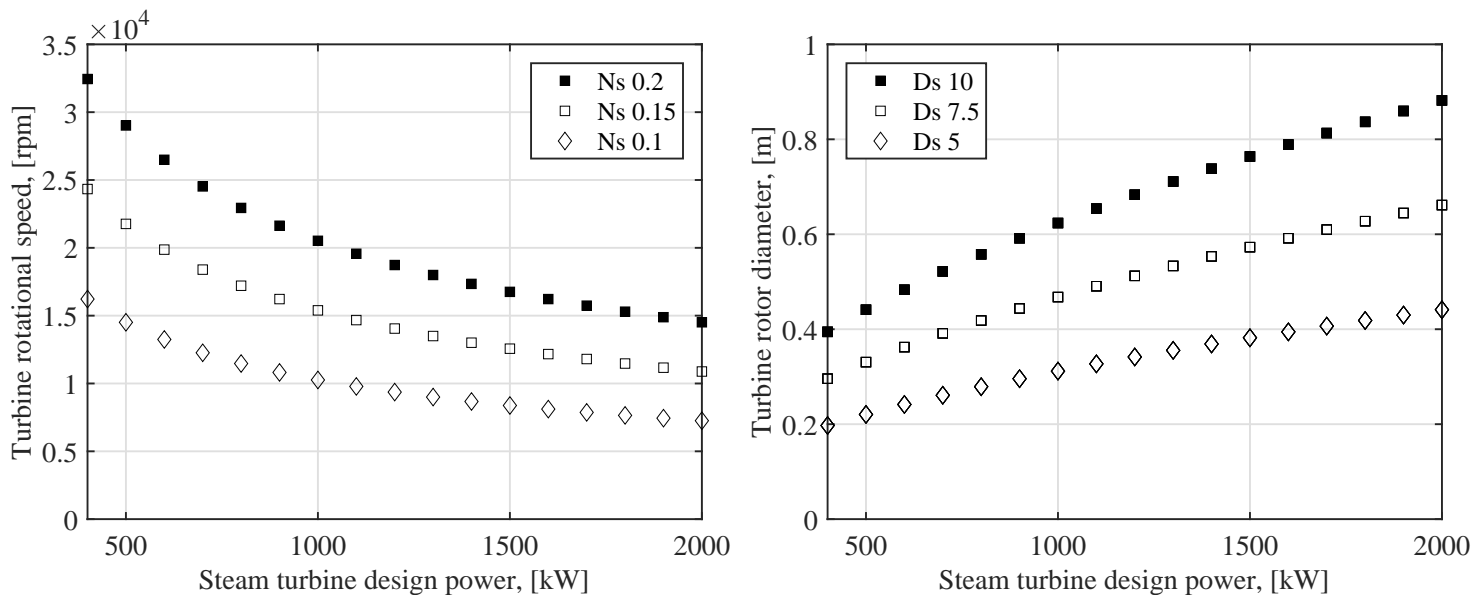

Figure 17: Effect of turbine specific speed on turbine rotational speed (a) and specific diameter on turbine diameter (b).

The results of the steam turbine design rotational speed and turbine rotor outer diameter are presented in Figures 18 and 19 for different turbine design powers and condensing conditions. These simulations were performed for both a one sided rotor design, in where the turbine blades are only on a one side of the rotor disk, and a two sided rotor design in where the turbine blades are on the both side of the rotor disk and the steam flow is divided equally for both sides. In the presented designs, suitable turbine diameter and rotational speed were estimated by using the the specific speed and the specific diameter similar to the 1 MW model turbine[31].

Based on the results, the turbine wheel is larger and the rotational speed is lower at high steam turbine design powers and with low condensing conditions. The turbine wheel size is more compact and the optimal rotational speeds are higher with the high condensing temperatures and in low power output designs. The turbine design with the largest turbine wheels might not be appropriate for radial outflow type of turbines, due to the large mass and large diameter of the impeller. In these cases, other type of turbines such as conventional multistage axial turbines could be considered as a more feasible choice for the turbine design instead of radial outflow turbine. The turbine diameter can be also designed to be smaller by increasing the rotational speed. The benefit of using the two sided design is the more compact turbine size when compared to the one sided design, but on the other hand, this type of design leads to the requirement of higher rotational speed. An additional benefit of using the two sided design is that the axial forces are significantly lower when compared to the one sided design, that results in reduced mechanical losses in the 

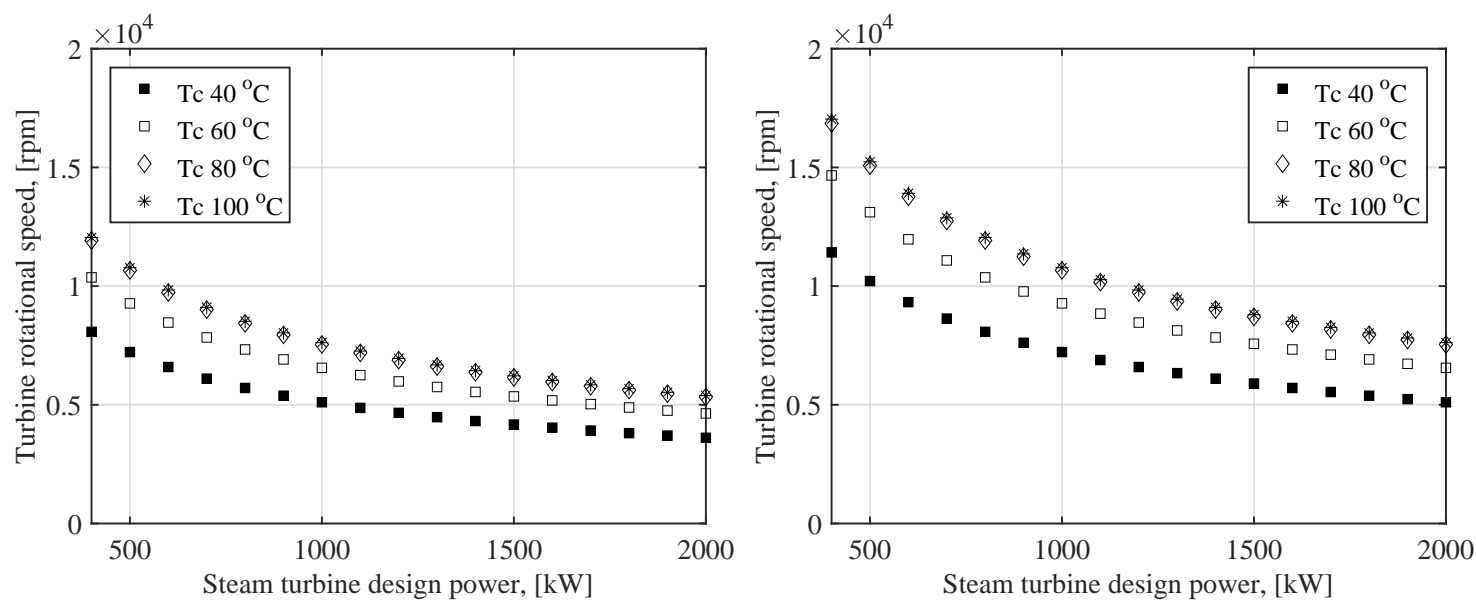

Figure 18: Optimal turbine rotational speed based on $N_{s}$ for one sided (a) and two sided designs (b).
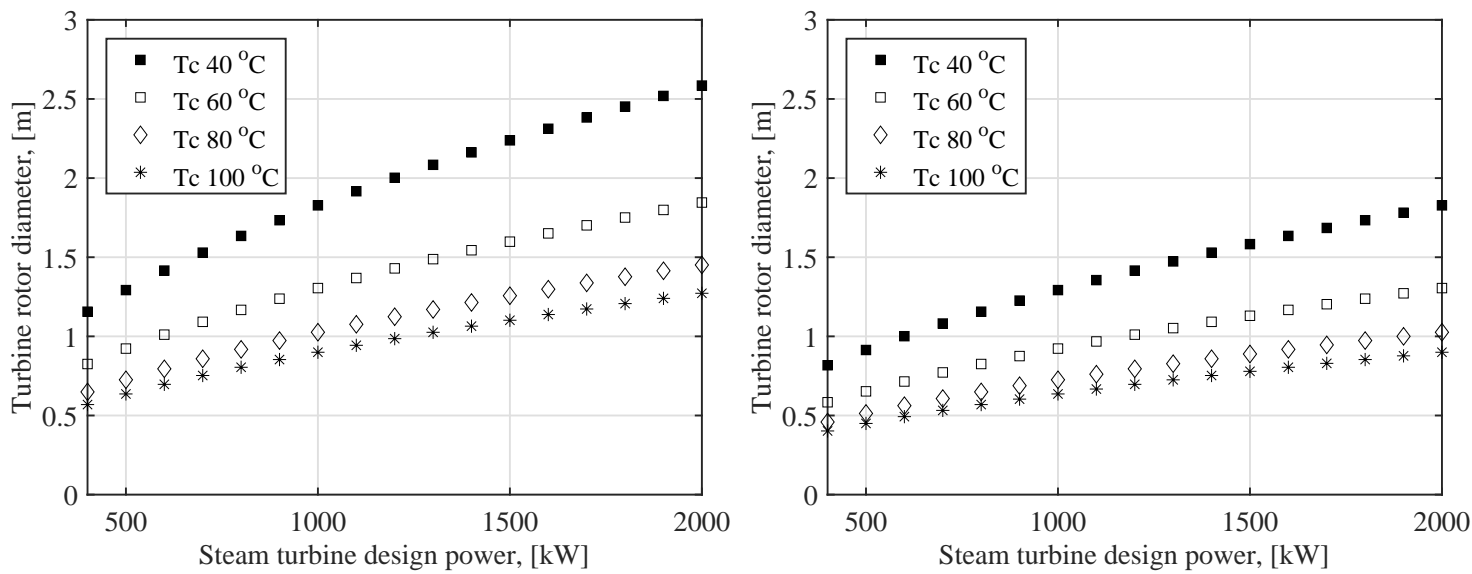

Figure 19: Optimal turbine diameter based on $D_{s}$ for one sided (a) and two sided designs (b).

turbogenerator system. Thus, more detailed investigations on the turbine geometry, optimal specific speed and optimal specific diameter should be carried out in the future, taking into account the turbine blade designs for each turbine stage and also to include more detailed loss analysis.

\section{Conclusions}

The utilization of the thermal power of excess steam into additional electricity production was identified to be an attractive technical option for increasing the electric efficiency of cruise ship energy systems and can thus, significantly contribute in reducing the fuel consumption and emissions of the ship operation. The main conclusions drawn from the study are summarized as follows:

1) The maximum annual electrical energy of $3920 \mathrm{MWh} / \mathrm{a}$ was estimated for Ship 1 and about 5300 $\mathrm{MWh} / \mathrm{a}$ for Ship 2. These results correspond to about 1 to $1.5 \%$ of the cruise ship total energy production. 
2) The electric power production potential is highly dependent on the steam turbine design power. The highest energy production values were simulated with the steam turbine design power ranging from $1 \mathrm{MW}$ to $2 \mathrm{MW}$.

3) The turbine design power that maximizes the energy production highly depends on the condensing temperature and on the operational profile of the ship. The use of a low condensing temperature results in higher optimal design power when compared to the higher condensing temperatures.

4) High turbine efficiency and capability for operating at wide range of steam flow conditions is required as the amount of steam for the turbine is highly fluctuating during the ship operation. During the stays in harbor, the studied WHR systems can not be operated, as there is no excess steam available, which reduces the energy production potential.

5) The combination of steam turbine and ORC using R245fa as the working fluid resulted in comparable energy production when compared to the steam turbine having a low condensing temperature. A more complex WHR cycle architecture is required in this case, but steam condensing pressures below the atmospheric pressure can be avoided.

6) The optimal steam turbine rotational speed and diameter are highly affected by the power scale and condensing conditions.

In this study, a new type of steam turbine system was studied and the steam turbine system has a multistage radial outflow turbine connected directly to a high speed generator. The main advantages of this type of systems were evaluated to be the compact size and it was estimated that higher off-design efficiency and wider off-design operational range can be reached, when compared to more conventional small-scale axial steam turbines equipped with gear box. The main disadvantages of the studied system is that at high power levels (above $2 \mathrm{MW}$ ) the turbine wheel becomes impractically large for the studied conditions. In addition, if low power output systems (less than 0.5 MW) are considered, the rotational speeds for reaching the optimal turbine operation become significantly high. Thus, the radial outflow turbines were considered to be suitable especially for from 0.5 to $2 \mathrm{MW}$ steam turbine systems that is the optimal size for a turbine power for utilizing excess steam flow in the studied cruise ship. A more detailed investigation on the waste heat recovery system performance and technical potential are recommended to be carried in the future, including experimental research with a full-scale steam turbine prototype installed in a cruise ship, to confirm the simulated results on the energy production potential. It should be also noted that in this study the utilization of excess steam heat was considered as the only heat source for the investigated WHR system. If the utilization of also other waste heat streams were combined to the studied systems, such as the utilization of the engine cooling heat, or a higher amount of steam could be utilized for power production instead of heating, higher energy production potential were reached. 


\section{Acknowledgements}

This study has been done within the B.U.S.I.N.E.S research project. The funding of the study by Business Finland (formerly Tekes - the Finnish Funding Agency for Innovation) and the companies that have been participating in the research project are greatly acknowledged.

\section{References}

[1] Vergara J., McKesson C., and Walczak M. (2012). Sustainable energy for the marine sector. Energy Policy, 49, 333-345.

[2] Basurko O.C. and Mesbahi E. (2012). Methodology for the sustainability assessment of marine technologies. Journal of Cleaner Production, 68, 155-164.

[3] Deniz C., and Zincir B., (2015). Environmental and economical assessment of alternative marine fuels. Journal of Cleaner Production, 113, 438-449.

[4] Baldi F., and Gabrielii C. (2015). A feasibility analysis of waste heat recovery systems for marine applications. Energy, 80, 654-665.

[5] Walsh, C., and Thornley, P. (2012). The environmental impact and economic feasibility of introducing an Organic Rankine Cycle to recover low grade heat during the production of metallurgical coke. Journal of Cleaner Production, 34, 29-37.

[6] Liu C., He C., Gao H., Xie H., Li Y., Wu S., and Xu J. (2013). The environmental impact of organic Rankine cycle for waste heat recovery through life-cycle assessment. Energy, 56, 144-154.

[7] Uusitalo A., Uusitalo V., Grnman A., Luoranen M., and Jaatinen-Vrri A. (2016). Greenhouse gas reduction potential by producing electricity from biogas engine waste heat using organic Rankine cycle. Journal of Cleaner Production, 127,399-405.

[8] Singh D. V., and Pedersen E. (2016). A review of waste heat recovery technologies for maritime applications. Energy Conversion and Management, 111, 315-328.

[9] Sprouse III C. and Depcik C. (2013). Review of organic Rankine cycles for internal combustion engine exhaust waste heat recovery. Applied Thermal Engineering, 51(1-2),711-722.

[10] Larsen U., Sigthorsson O., and Haglind F. (2014). A comparison of advanced heat recovery power cycles in a combined cycle for large ships. Energy, 74, 260-268.

[11] Bombarda P., Invernizzi C.M. and Pietra C. (2010). Heat recovery from Diesel engines: A thermodynamic comparison between Kalina and ORC cycles. Applied Thermal Engineering,30(2-3),212-219.

[12] Uusitalo A., Honkatukia J., Turunen-Saaresti T., and Larjola J. (2014) A thermodynamic analysis of waste heat recovery from reciprocating engine power plants by means of organic Rankine cycles. Applied Thermal Engineering, 70(1),33-41.

[13] Larsen U., Nguyen T.V., Knudsen T., and Haglind F. (2014). System analysis and optimisation of a Kalina split-cycle for waste heat recovery on large marine diesel engines. Energy, 64, 484-494.

[14] Theotokatos G, Livanos GA. (2013). Modern concepts of ferries propulsion plant for reducing fuel consumption cost and CO2 emissions. In: Low carbon shipping conference. London; 2013.

[15] MAN Diesel \& Turbo, Waste Heat Recovery System (WHRS) for Reduction of Fuel Consumption, Emissions and EEDI

[16] Ichiki Y., Shiraishi K., Kanaboshi T., Ono Y., and Ohta Y. (2011). Development of Super Waste-Heat Recovery System for Marine Diesel Engines, Mitsubishi Heavy Industries Technical Review Vol. 48 No. 1, Mach 2011.

[17] Ahnger A. (2007). ECC with internal combustion engines. Wartsila technical journal.

[18] Invernizzi C., Iora P., and Silva P. (2007). Bottoming micro-Rankine cycles for micro-gas turbines. Applied thermal engineering, 27(1), 100-110. 
[19] Chacartegui R., Sanchez D., Munoz J. M., and Sanchez T. (2009). Alternative ORC bottoming cycles for combined cycle power plants. Applied Energy, 86(10), 2162-2170.

[20] Hou S., Wu Y., Zhou Y., and Yu L. (2017). Performance analysis of the combined supercritical CO2 recompression and regenerative cycle used in waste heat recovery of marine gas turbine. Energy Conversion and Management, 151, 73-85.

[21] Riffat, S., and Ma, X., (2003). Thermoelectrics: a review of present and potential applications. Applied Thermal Engineering 23, 913-935.

[22] Karvonen, M., Kapoor, R., Uusitalo, A., and Ojanen, V. (2016). Technology competition in the internal combustion engine waste heat recovery: a patent landscape analysis. Journal of Cleaner Production, 112, 3735-3743.

[23] Ahlgren, F., Mondejar, M. E., Genrup, M., and Thern, M. (2016). Waste heat recovery in a cruise vessel in the Baltic Sea by using an Organic Rankine Cycle: A case study. Journal of Engineering for Gas Turbines and Power, 138(1), 011702.

[24] Grljuic, M., Medica, V., and Racic, N. (2014). Thermodynamic analysis of a ship power plant operating with waste heat recovery through combined heat and power production. Energies, 7(11), 7368-7394.

[25] Song, J., Song, Y., and Gu, C. W. (2015). Thermodynamic analysis and performance optimization of an Organic Rankine Cycle (ORC) waste heat recovery system for marine diesel engines. Energy, 82, 976-985.

[26] Rech S., Zandarin S., Lazzaretto A., Frangopoulos C.A. (2017). Design and off-design models of single and two-stage ORC systems on board a LNG carrier for the search of the optimal performance and control strategy. Applied Energy, 204, 221-241.

[27] Martin C., and Kolenc T. (1979) Study of advanced radial outflow turbine for solar steam Rankine engines. NASA report.

[28] Gronman A., Uusitalo A., and Backman J. (2017) Loss generation in radial outflow steam turbine cascades, 12th European Conference on Turbomachinery Fluid Dynamics and Thermodynamics, Stockholm; Sweden

[29] Leino M., Uusitalo V., Gronman A., Nerg J., Horttanainen M., Soukka R., and Pyrhonen J. (2016). Economics and greenhouse gas balance of distributed electricity production at sawmills using hermetic turbogenerator. Renewable Energy, $88,102-111$

[30] Casati E, Vitale S, Pini M, Persico G, and Colonna P. (2014). Centrifugal Turbines for Mini-Organic Rankine Cycle Power Systems. ASME. Journal of Engineering for Gas Turbines Power. 136(12), 10.1115/1.4027904.

[31] Lappeenranta University of Technology and Saimaa University of Applied Sciences HERGE-project(unpublished information).

[32] Uzhegov, N., Kurvinen, E., Nerg, J., Pyrhonen, J., Sopanen, J., Shirinskii, S., (2016). Multidisciplinary Design Process of a 6-Slot 2-Pole High-Speed Permanent Magnet Synchronous Machine. IEEE Transaction on Industrial Electronics, 63(2), 784-795.

[33] Branchini, L., De Pascale, A., and Peretto, A. (2013). Systematic comparison of ORC configurations by means of comprehensive performance indexes. Applied Thermal Engineering, 61(2), 129-140.

[34] Colonna P., Casati E., Trapp C., Mathijssen T., Larjola J., Turunen-Saaresti T., and Uusitalo A. (2015). Organic Rankine cycle power systems: from the concept to current technology, applications and an outlook to the future. Journal of Engineering for Gas Turbines and Power, 137,10.1115/1.4029884.

[35] Uusitalo A., Honkatukia J., Turunen-Saaresti T., and Grnman A. (2018) Thermodynamic evaluation on the effect of working fluid type and fluids critical properties on design and performance of Organic Rankine Cycles. Journal of Cleaner Production, pp. 258-263.

[36] Declaye S., Quoilin S., Guillaume L., and Lemort V. (2013). Experimental study on an open-drive scroll expander integrated into an ORC (Organic Rankine Cycle) system with R245fa as working fluid. Energy, 55, $173-183$.

[37] Kang S.H. (2012) Design and experimental study of ORC (organic Rankine cycle) and radial turbine using R245fa working fluid. Energy, 41(1),514-524.

[38] Wang J. L., Zhao L., and Wang X. D. (2012). An experimental study on the recuperative low temperature solar Rankine 
cycle using R245fa. Applied energy, 94, 34-40.

[39] Schobeiri, M. (2005). Turbine aerodynamic design and off-design performance. In Turbomachinery Flow Physics and Dynamic Performance (pp. 409-437). Springer Berlin Heidelberg.

[40] Balje O. E. (1981). Turbomachines-A guide to design, selection, and theory. John Wiley and Sons.

[41] Lemmon E.W, Huber M.L., and McLinden M.O. (2010). Reference fluid Thermodynamic and Transport Properties (REFPROP), Version 9.0, National Institute of Standards and Technology

[42] Uusitalo A. (2014). Working fluid selection and design of small-scale waste heat recovery systems based on organic Rankine cycles. Doctoral thesis, Lappeenranta University of Technology, Finland.

[43] Hu D., Zheng Y., Wu Y., Li S., and Dai Y. (2015). Off-design performance comparison of an organic Rankine cycle under different control strategies. Applied Energy, 156, 268-279.

[44] Kraus M. H., Deichsel M., Hirsch P., Opferkuch F., and Heckel C. (2016, June). Hermetic 40-kW-Class Steam Turbine System for the Bottoming Cycle of Internal Combustion Engines. In Proceedings of the ASME Turbo Expo.

[45] Wärtsilä Engines 46DF Product guide 